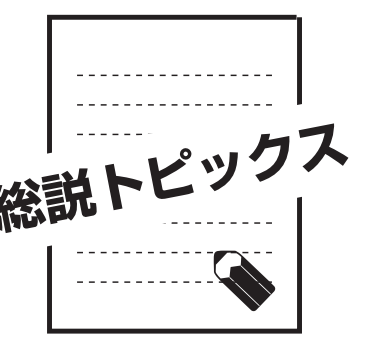

\title{
サイエンスとアートの協奏
}

\section{Concert of Science and Art}

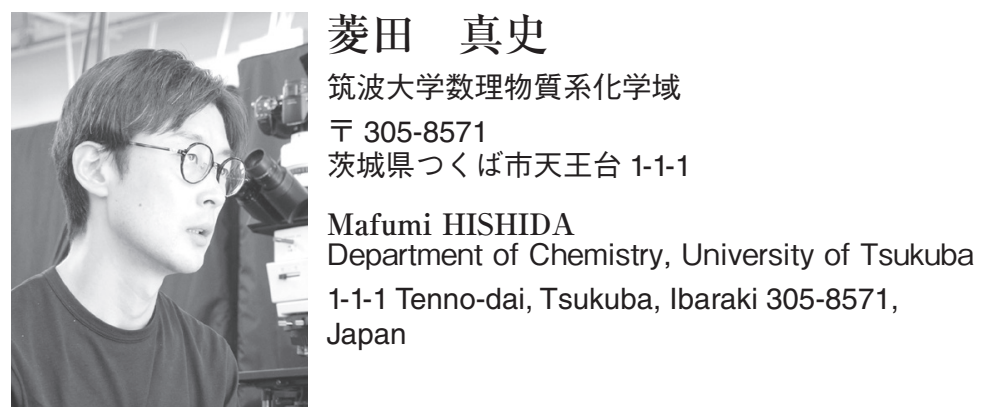

論文要旨: 筆者は, 大学において油化学, コロイド化学, ソフトマター物理学の研究を行う傍ら, 科学と いう営みを表現するべく現代アート活動を行っています。本稿では，これまで制作・展示してきた作品の紹 介，拉よび，どのような考えのもとに科学とアートの協奏的な活動を行っているのかについて，ご紹介させ ていただきます。

\begin{abstract}
In addition to the scientific researches in the field of oleo-science, colloid chemistry and soft matter physics, the author is performing the contemporary art to represent the essence of the science. In this article, I would like to introduce my art works exhibited in the events and to present why I am performing the science-art activities.
\end{abstract}

\section{1 はじめに}

筑波大学の菱田真史と申します。私は普段はソフトマ ター物理学, コロイド化学, 油化学, 物理化学, 生物物 理学などにまたがって研究を行っております。特にリン 脂質膜を中心にした両親媒性分子の自己組織化に興味を もち, 様々な角度からそのメカニズムを探るという研究 を行ってきています ${ }^{1)}$ 。一方で, 科学的な知見を活かし た現代アートの作家としてアーティスト活動も行ってい ます。とくに，サイエンスという営みをアートとして表 現するということを目指して活動を行っています。普段 の研究活動とは離れたこういった活動について, 本誌面 に記事を書かせていただく機会をいただけましたので, サイエンスとアートの関係性や, アートと油化学・コロ イド化学との親和性などについて, 作品の紹介を交えな がら私が普段考えていることを述べさせていただければ と思います。初めにお断りしておきたいのは, 本稿で述 べる科学感は筆者の個人的な感覚であり, 科学者の一般

連絡者：菱田 真史

E-mail : hishida@chem.tsukuba.ac.jp
に通じるものでは全くないこと, またここで述べる科学 というのがいわゆる純粋基礎科学のことを指していると いうことです。科学者はみな科学に対して情熱を持って いるかと思いますが, その方向性は様々かと思いますし, そのような多様性は科学の発展に重要です。ここでは, このような考え方をする科学者もいるのだという程度に 捉えていただければ幸いです。

\section{2 科学の美}

アート活動を行うことになったきっかけや考えを書か せていただくためには，まずは私の科学研究の来歴につ いてご紹介させていただくのが良いかと思います。私は 京都大学の理学部物理学科において研究をスタートさせ たときから一貫して, ソフトマターの自己組織化現象に 魅せられて研究を行ってきました。特にリン脂質二重膜 ベシクルの形態形成やダイナミクスなど, 物理学・化学· 生物学の境界に存在し, いずれの分野においても重要な 問題を解き明かすことを楽しんで研究を行っています1)。 リン脂質ベシクルを顕微鏡で観察すると様々な形態や動 きが観察されますが，それはシンプルな物理によって記 
述されるだけでなく，生命現象とも深くかかわっていま す。顕微鏡で見た姿だけでなく，そこに潜んでいる科学 そのものの美しさに魅せられたのが最初に科学とアート の協奏関係を意識したきっかけでした。また油化学，コ ロイド化学, ソフトマター物理学の中にはリン脂質ベシ クルだけでなく，目で見て純粋に美しいと感じられる現 象が沢山あります。たとえば，顕微鏡で観察した時の液 晶のパターンや自発的に動き回る液滴，水滴が滴下する 際の形態変化, ミルククラウン, シャボン玉の構造色, 雪の形状…。これら日常にも見られるパターン, 動き, 色, 模様など ${ }^{2}$ を研究の中で学び体験する中で, こういっ た世界の美しさを我々科学者が知っているだけというの はもったいない，是非，一般の方々にも知っていただき たいという思いが強くなってきました。また，もともと 子供のころからアートが好きで，アーティストや芸術系 の大学の学生などの友人が多く，彼らにこれらの科学現 象を見せた時の反応の良さからも，科学現象とアートの 親和性の高さや科学のアート表現というものの可能性に 気づかされていました。

科学のアート表現に関する考えについて詳しくは本稿 の後半で述べさせていただくことにして，ここからはこ れまでに行ってきたアート活動についてご紹介せていた だきます。

\section{3 美術館での講演, 対談}

上述のように，日々美しい現象を眺めながら研究を 行っているなかで，芸術系の友人知人にその映像を見せ たり話をしたり，ということがありました。そういった ことを続けているうちに，徐々に興味を持っていただけ ることが多くなっていき，博士号を取得する前後から美 術館などでの講演 ${ }^{3)}$ を頼まれるようになったのが，アー 卜業界との関わりをもったきっかけです。美術館で作品 を展示中のアーティストとの対談などを行う中で，科学 とアートの関係性や親和性, 科学とテクノロジーの関係 性などについて私なりの考えをお話しさせていただく機 会が多くありました。そうして多くのアーティストと交 流し, 様々な考え方に触れたことによって, 自らの科学 感というものが醇成され，またそれをアートとして表現 したいという思いが大きくなっていきました。こういっ たアート活動を通して醸成されてきた科学感は，(おそ らく）普段行っている科学研究にも大きく反映されてい ると感じています。

\section{4 アートハッカソン「干渉する浮遊体」}

実際に作品制作を行うようになったきっかけは，友人 に誘われて 2015 年に開かれたハッカソン（KENPOKU
Art Hack Day) ${ }^{4)}$ に参加したことです。近年ハッカソン イベントは様々な場所で見られるようになってきまし た。ハッカソンとは様々な技量を持つ専門家が集まり， その場で初めて会う者同士でチームを作り, 何らかの制 作や活動を行い，チーム同士でその成果を競いあうイベ ントです。もっとも広範に行われている分野はアプリ作 成をはじめとしたWEB テクノロジー・インターネット テクノロジーの世界です。種々の技量を持つプログラ マーが集まってアプリやWEB 等の制作を行うイベント が各地で開催されています。最近では地方活性化にむけ た企画を行うものなど，目的が多様化してきています。 参加者の多様性の中で全く新しい発想が生まれてくる可 能性が高くなるため，様々な企業や団体が新しい企画ア イデアを収集したり，社会に対して新しい刺激を与えた りする際に盛んに用いられるようになってきています。

WEB・ITの世界と親和性が高いメディアアートの世 界においても同様のイベントが開催されるようになって きています。私が参加したKENPOKU Art Hack Dayも， 目的をアート作品制作に限ったものでした。とくにそこ でのミッションは, 2016 年に開かれる現代アートの国 際芸術祭である茨城県北芸術祭 ${ }^{5)}$ への参加作品を提案 するというものでした。応募者の中からアーティストや 建築家, 音楽家, プログラマー, 技術者, 研究者など様々 なバックグラウンドを持つ 60 名が選抜され，前半二日 でチームを結成し，後半二日で実際の作品を制作しプレ ゼンを行うというものでした。

こういった現代アートの芸術祭は特に過疎化が進む地 方の活性化に有効であることから，近年日本各地で開か れています。 3 年ごとに香川県の島々で開かれる瀬戸内 国際芸術祭や新潟県で開かれる越後妻有大地の芸術祭, 名古屋を中心に行われるあいちトリエンナーレなどがと くに有名で，これらは期間中 100 万人近くの観客が訪れ ることもあります。茨城県北芸術祭もこのような目的の もと，県が大々的に企画した芸術祭でした。ハッカソン イベント自体も県のサポートのもと, 県内の様々な場所 の視察や交流イベントなどが開かれました。

ハッカソンでは前半 2 日間は会場各地の視察とメン バー同士での交流会が開かれ ${ }^{6)}$ ，個々人の様々な考えを ぶつけあう場となりました（Fig. 1)。2 日目の最後に本 芸術祭でどのような作品を展示したいかをプレゼンする ことになり，強い思いのある 30〜40 名がプレゼンを行 いました。私は科学者の目線から，「日常に潜んでいる 自然現象の美しさを表現することで茨城県北地域の自然 の美しさを再認識させるような作品を制作したい」とい うプレゼンを行いました。プレゼンターも含め, 他のメ ンバーは参画したい企画に投票する形となっており，多 


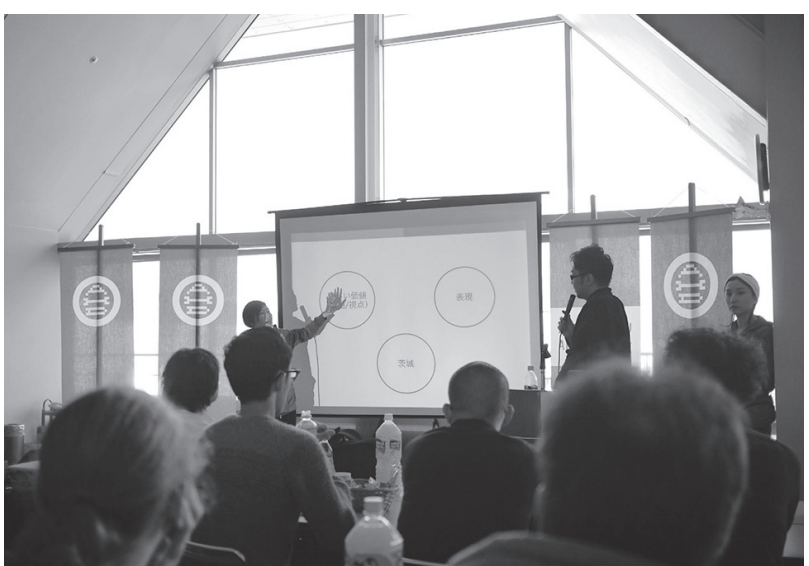

Fig. 1 KENPOKU ART Hack Day二日目の風景。

くの票を集めた 13 企画が実際にプロトタイプ制作を行 うことになりました。そこから 2 週間の間，私の案に投 票していただいてメンバーになった方々と, どう作品化 するのかについて日夜話し合い, 後半 2 日間でプロト夕 イプ作品の制作となりました。私のチームにはガラス彫 刻家, 音楽家, プログラマー, デザイナー, 建築家を専 門とする方々に参加していただき，「自然の美しさの再 認識」をシャボン玉を用いて表現したいという私の思い を表現するために，様々なアイデアや技術を提供してい ただきました。2 日間の急場でしたが，ほぼ徹夜の作業 で，「干渉する浮遊体」のプロトタイプ制作を行いまし た ${ }^{7)}$ 。

「干渉する浮遊体」帛はシャボン玉の構造色を最大限に 鮮やかに体験的に鑑賞できる作品です (Fig. 2)。二酸化 炭素で満たしてある大きなガラスの器の上からシャボン 玉がふり注ぎます。シャボン玉は二酸化炭素よりも軽い ため, ガラスの器の中でほぼ完全に 1 分以上も静止する ことになります。さらに鑑賞スペースをモノトーンにデ ザインすることでシャボン玉への風景の映り込みを避 け，光の当て方を工夫することで最大限に構造色を鮮や かに見えるように空間設計を行いました。シャボン玉の 構造色は教科書的には当たり前ですが，ここまで鮮やか なものを見たことがある方はなかなかいらっしゃらない だろうと思えるほどに鮮やかなシャボン玉を長時間鑑賞 できるものとなりました。シャボン玉にはっきりと色が 付くことでカメラによる認識が可能となり, 音や映像と シャボン玉の動きを同期させることもできました。そこ で, シャボン玉が割れると音が鳴るなどの仕掛けを作る ことで, 全く新しい鑑賞体験を生み出すインスタレー ション作品としました。

誰もがなんとなくきれいだなという認識のあるシャボ ン玉ではありますが, その想像を超える本当の鮮やかさ を提示することで，「自然の中には今まで気付かれてこ
なかった美しさが隠れている」ということを表現しまし た。そこには, 茨城県北地域, ひいては自らの身の回り の自然にも，これまで思っていた以上に美しい本来の姿 が潜んでいるかもしれないというメッセージが含まれて います。これはシャボン玉本来の鮮やかさを最大限に見 せたいという私の思いと他のメンバーの技量が合わさる ことで初めて成功した作品でした。

4 日目の最後に茨城県北芸術祭のディレクターである 南條史生さんをはじめとする審査員の前で発表（実際の 作品展示だけでなく, コンセプトや実現可能性, コスト, 茨城県北地域への貢献なども）を行い，審査が行われま した 9)。その結果, 本ハッカソンでのグランプリをいた だくことができ, 次年開催の茨城県北芸術祭へ招待作家 として参加させていただくことが決まりました。審査意 見では, “シャボン玉とは消えるもの。その先入観を軽 快に裏切るのがこの作品である。本当にシャボン玉なの かと目を疑ってしまうほど安定感をもって, 空中に浮遊 する。流動しながら, 微細な空気の流れに呼応して, 浮 き沈み, 漂い, 結びつき, そして消滅する。そして音が, シャボン玉の動きに感情を与える。シャボン玉の科学者, ガラス作家，そして音や映像といったエンジニアのチー ムだから実現した，ハッカソンならではの作品であり， 驚きを感じさせる作品だった。また芸術祭で展開するに あたり，およその技術的課題がクリアされており，運用 面, 予算面も具体的に検討されている点も高く評価し た。”との評価をいただきました。

\section{5 茨城県北芸術祭「干渉する浮遊体」}

KENPOKU ART 2016 茨城県北芸術祭 ${ }^{5)}$ は 2016 年 9 月 17 日（土） 11 月 20 日（日）の 65 日間に茨城県の 県北地域（日立市, 高萩市, 北茨城市, 常陸太田市, 常 陸大宮市，大子町）で開かれた現代アートの国際芸術祭 です。国内外から 100 組近くのアーティストが参加し, 77 万人以上の観客を集めた日本最大級の芸術祭でした。

我々のチームは, 茨城県大子町にある麗潤館という古

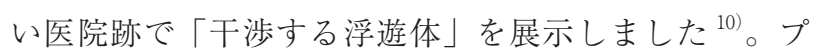
ロトタイプの段階では $50 \mathrm{~cm}$ 程度であったガラスの器 のサイズを直径約 $1.2 \mathrm{~m}$ と大型化し, $3 \mathrm{~m} \times 3 \mathrm{~m}$ 程度の 部屋の光環境をデザインし直して作品を展示しました ${ }^{8)}$

(Fig. 3)。

シャボン玉が天井裏から一定時間間隔でガラスの器の 上に降り注ぐように, 自作のシャボン玉発生器を配置し, 降り注ぎ滞留するシャボン玉の動きをカメラで認識, そ れに応じて音や映像がインタラクティブに生成される作 品として展示しました。展示に際してはあえて科学的な 説明などは省くことで，鑑賞者それぞれに個々のストー 


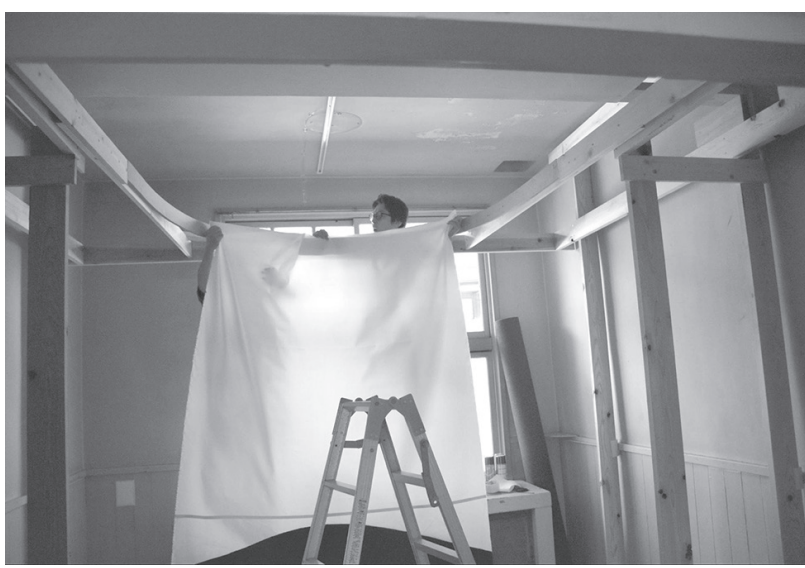

Fig. 3 茨城県北芸術祭において「干渉する浮遊体」の制作 作業中の筆者。

リーを呼び覚まさせることを意識しました。また仕掛け を明示しないことで，鑑賞後にもその不思議を考え続け させるようにも意識した展示を行いました。このように 鑑賞者それぞれが自由に自分自身の感覚を呼び覚ますこ とができるというのが，現代アートの最も重要な役割で しょう。

本作品は 2 か月間の展示で延べ 1 万人以上の方に鑑賞 していただきました。2か月間の展示は非常に長く，装 置の故障などのトラブルもありましたが，なんとか大き な問題なく乗り切ることができました。作家として滞在 中, 鑑賞者の方々からは「科学の本当の面白さを感じた」 「アートの概念を覆された」「想像以上の美しさだった」 など様々なご感想をいただき，日によっては行列になっ たり海外の情報サイトに注目作品として揭載していたた いたりするなど，大変な好評をいただくことができまし た。このように一般の方々と意見を交換したり感想をい ただいたりする機会は普段の研究生活ではほとんどない ため，大変刺激のあるものです。また会期後に，芸術系 のいくつかの賞 ${ }^{11)}$ を受賞させていただき，東京での展

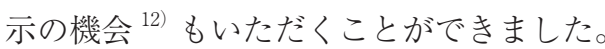

\section{BIWAKO ビエンナーレ「泡影」}

茨城県北芸術祭での展示以降，アート業界とのつなが りやロコミ，また上述のハッカソンイベントで競い合っ た方々からの紹介などで，定期的に作品を発表する機会 をいただけています。

たとえば，ディレクターの方から拉声がけいただき， 滋賀県近江八幡市で 2 年に一度開かれている国際芸術 祭, BIWAKO ビエンナーレ ${ }^{13)}$ に参加させていただい ています。BIWAKO ビエンナーレ 2018 では，「干渉す る浮遊体」からスピンアウトし, 私個人の独立作として 同様の仕組みを使ってシャボン玉の影を魅せる作品「泡

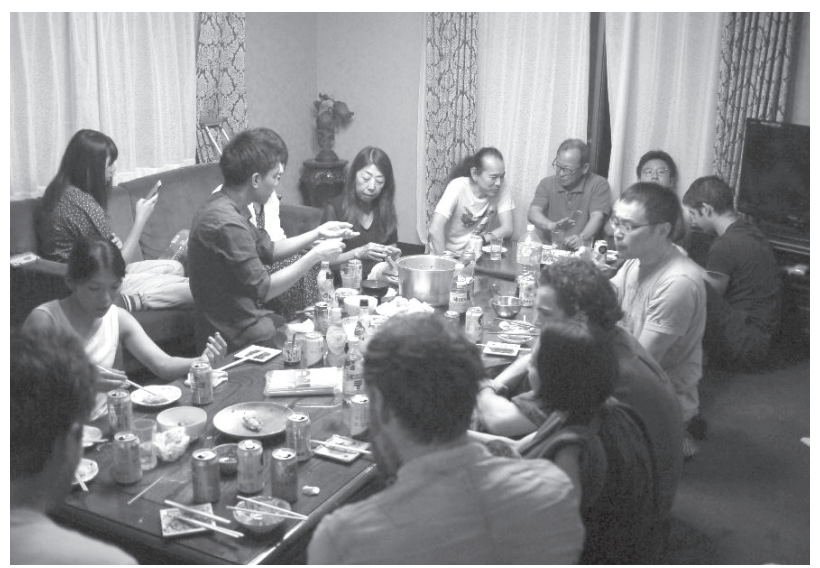

Fig. 5 BIWAKO ビエンナーレ 2018 制作時, 他の作家との 交流風景。

影」を制作・展示しました ${ }^{14)}$ (Fig. 4)。

ここでは静止するシャボン玉の影（シャボン玉の影に は構造色を反映した色が付きます）を見せることに集中 した作品としました。会場は江戸時代から続いた酒蔵跡 の町家で, 江戸時代の䨌囲気がそのまま残る力強く陰影 深い空間との対比が美しい作品となりました。また BIWAKO ビエンナーレでは空間を区切ることなく各作 家の作品を展示しているため, 他の作品とも呼応し, 独 特の空間を作ることができました。シャボン玉を浮かべ る器などの作品の一部はその場で昔から使われていた夕 ライなどを用い，実際に日本酒を醉造していた空間での 展示になったことからか, 敖の発酵のような生命性を带

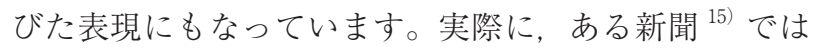
「(シャボン玉の) 球一つ一つが, 原子生命体のように呼 吸し, 脈動し, 生きているようにも見え, 神秘的な世界 に陶然となった。とご紹介いただきました。私が普段 リン脂質膜ベシクルを研究しており, 脂質膜に生命の根 源のようなものを感じながら研究を進めているだけに, 類似の構造を持つシャボン玉をこのように捉えていただ けたことはとてもうれしく，また新鮮に感じました。

また, 茨城県北芸術祭や BIWAKO ビエンナーレは多 くの作家が一堂に集まって作り上げられる芸術祭である ため，ほかの作家との交流が盛んに行われます。 BIWAKO ビエンナーレでは他の作家とともに一つの家 に泊まり込み，皆で食事を共にし，意見をぶつけ合い， また共感しながら作品制作を行っています（Fig. 5)。我々 研究者とは別の角度からの（ともすると否定的になりが ちな）科学に対する考え方をもつ方々に科学の本質を説 明することで，肯定的な感覚を引き出すことができた際 には非常に喜びを感じるものです。BIWAKO ビエン ナーレには 2020 年にも参加させていただく予定です。 


\section{7 六本木アートナイトほか「dyebirth」}

シャボン玉を用いた作品の他には「dyebirth（ダイバー ス) 」6) という作品も制作しています（Fig. 6)。こちら は私が参加する以前より結成されていた nor ${ }^{17)}$ という チームに相談を受けて制作に参加させていただいた作品 です。nor もアートハッカソンイベントで生まれたチー ムであり, プログラマー, エンジニア, 音楽家, 建築家, プランナー，デザイナーなどからなるチームです。 KENPOKU Art Hack Day の際に知り合ったメンバー の一人から声をかけていただき，作品制作に参加させて いただきました。

「dyebirth」では粘性の異なる二つの液体が混ざる時 に特徵的なパターンが生まれる viscous fingering ${ }^{18)}$ ，お よび，表面張力に勾配がある場合に流れが生じるマラン ゴニ効果 ${ }^{19)}$ を、インクを使って鮮やかに見せています。 $3 \mathrm{~m}$ 近くある大きなパレット上に様々な色のインクがデ ジタル制御によって自動で滴下され，自発的にパターン を形成していく作品です。このようなパターン形成は油 化学や界面化学, ソフトマター物理学の研究分野ではよ く観察され，科学的な言葉を使うならば散逸構造 ${ }^{20)}$ の 一種といえます。物理学的に見ると, 非平衡状態の中で 創発的に機能や形態が生まれている生命もまた散逸構造 ととらえることができます。「dyebirth」において一日 かけて複雑な模様が自発的に生成される様は，おのずと 生命性を感じさせるものとなっています。規則的なデジ タル制御と, 予測不能な自然現象の狭間で様々な模様が 生まれ，染まり合い，やがて無個性な黒となり死んでい く一連の様子から, 多様な生命のあり方を見出すことが できる作品となっています。

制作では私は主に科学面担当で, 建築家やエンジニア など各メンバーの技量を組み合わせることで完成した作 品でした。実は「dyebirth」で見られる高粘性液体表面 上での低粘性液体の自発的な広がりによる fingering パ ターンの生成メカニズムは十分にわかっておらず，学問 的には未解明の新しい現象をつかった表現にもなってい ます。美しい現象を見出そうとするメンバー全員の探求 心と多くの予備実験の結果発見できた現象であり, 科学 とアートの協同による可能性を感じさせる制作となりま した。

こちらは, 六本木アートナイト (2017 年) ${ }^{21)} や$ Media Ambition Tokyo（2018 年) ${ }^{22)}$ といった都内中心部で行 われたアートイベントにて展示を行ってきたほか, 最近 では中国での展示 ${ }^{23)} も$ 行っています。また多くのメディ アにも載せていただき，国内外で芸術系の賞 ${ }^{24)}$ も受賞 させていただいています。

\section{8 摇らぎの美しさ「Flux/N-IL」}

立体によるインスタレーション作品だけでなく，映像 による制作も行っています。「Flux/N-IL」は液晶の顕 微鏡映像を利用した作品です $(\text { Fig. 7 })^{25)}$ 。サーモトロピッ ク液晶の相転移温度直上に温度を設定することで, 周辺 の温度の摇らぎの中での相転移の反復を引き起こしてい ます。この作品では, 自然の中で普遍的に存在している ものの，普段直接感じることの少ない「摇らぎ」の美し さを表現しています。自然な「摇らぎ」はいまだに CG などのテクノロジーでは表しきれません。そのため本作 品は $\mathrm{CG}$ 映像とは一線を画す妖艶さがあります。実際に は周囲の風などに呼応して $0.1 \sim 0.5^{\circ} \mathrm{C}$ 程度わずかに温度 が摇らぐことによって状態が変化しており，人為的では ない, 自然の摇らぎが映像におけるダイナミックな変化 を生み出しています。さらに有機的な音楽を合わせるこ とで, 宇宙のような生命のような得も言われ撼覚を呼 び起こす作品となっています。このようなわずかな温度 変化での流転はほとんど過冷却のない液晶材料を用いて 初めて観察されたものです。液晶の映像は我々専門家か らすると日常的なものですが，一歩専門を離れてみると とても非現実的なものに見えてきます。音楽制作は「干 涉する浮遊体」の制作をともにした音楽家の方 ${ }^{26)}$ にお 願いしています。

こちらの作品は現在はインターネット上のみで発表し ていますが，いずれ古民家などの大きな空間で展示でき ればと考えています。

\section{9 科学とアートの親和性}

日常的に科学活動, とくに非常に基礎的な科学研究を 行っていると, 科学とは本来如何なるものなのか, 元々 の目的は何なのか, 人類社会にどのように関わり役に立 つことができるのか，といったことを考えざるを得ませ ん。特に自分自身のバックグラウンドが物理学にあるた め, ここでの考えは必然的に物理学的な発想が主体に なっているかと思います。物理学とは個別の事象に注目 して研究を行っているように見えるものの, 最終的には 普遍的な物事の理解を目指す学問です。それが物の理(こ とわり）を理解するということかもしれません。物質が 異なったり，スケールが異なったり，そもそも事象が異 なったりしていても, 同じ機構で物事を理解したい, 理 解できるに違いないと信じて進めていく学問であるよう に思います。物理学に限らず科学というものは自然を俯 瞰的に理解し本質を見出すことを目指していると考えて います。それを行い続け，突き詰めることで，自分自身 の確固たる人生観を確立し, 自ら納得した豊かな人生を 

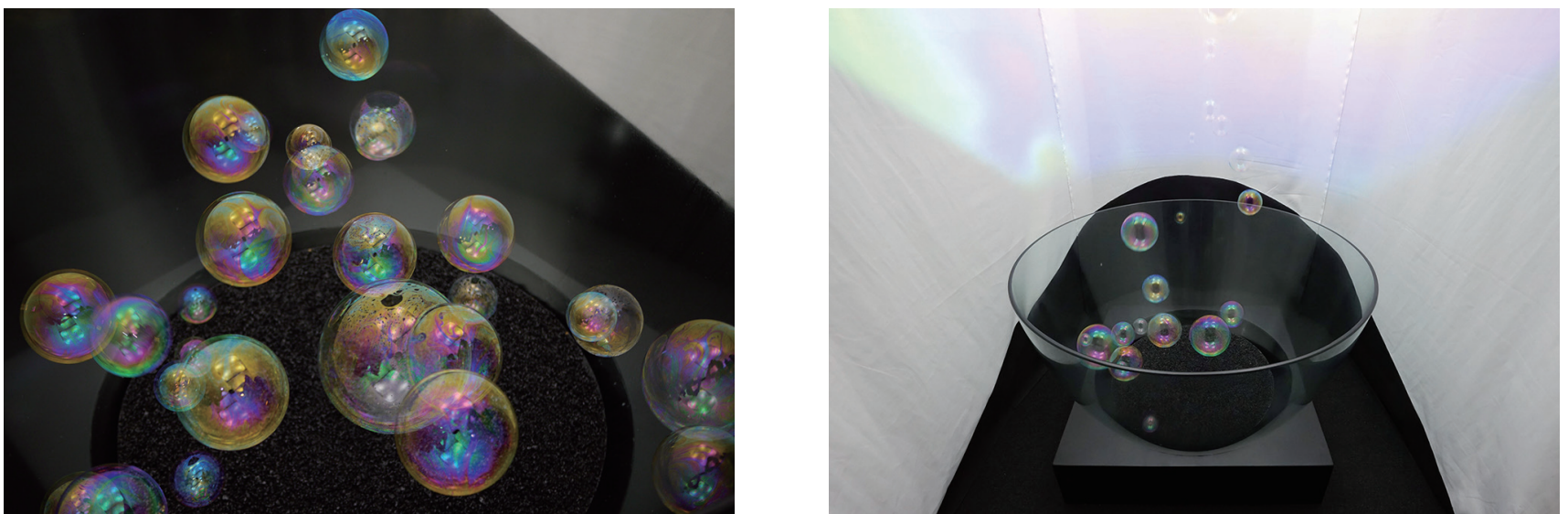

Fig. 2 「渉する浮遊体」(KENPOKU ART 2016 茨城県北芸術祭)。ガラスの器の直径は約 1.2 m。
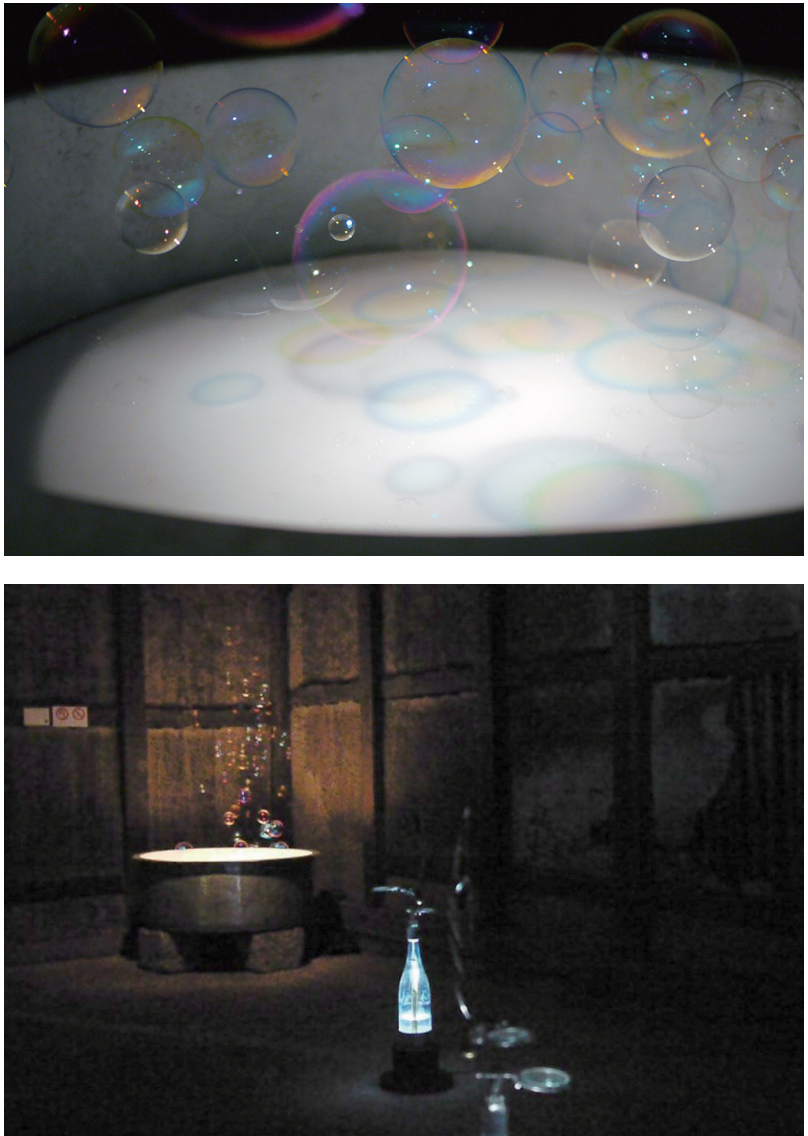

Fig. 4 (上)「泡影」(下) BIWAKO ビエンナーレ 2018 展示 風景 (奥が「泡影」)。

送ることができるようになってくるものだと思っていま す。すなわち，ただひたすらに自然の面白さと美しさを 知り，感動し，それを表現したいという哲学的かつ文化 的な目的そのものが科学活動の核心ではないでしょう か。

一方で, アートとは何か。アートの本質を言葉で表現 するのは非常に難しいですし，個々人によっての定義も 大きく異なるように思うため, 断定的には書くことがで
きませんが，私はアートとは自然というものの表現であ ると捉えています。ここでいう自然とは, いわゆる海や 森といった狭義の自然だけでなく，人間，社会，思想， などありとあらゆるものを含んでいます。それらを自ら の感性を通して表現するのがアートであるように捉えて います。本質は「自然の表現」です。つまり, 本質的に はアートと科学は非常に思想が近いものであると考えて います。アートは表現対象にも表現方法にも制限はあり ませんが，科学は実質的にそれらの制限があるため，科 学はアートの一部であると捉えることもできるのではな いでしょうか。

一見かけ離れたもののように見える科学とアートです が, いずれも人類の文化的, 精神的な豊かさを向上させ る営みであるという意味で，その思想は非常に近いとみ ることができるのです。

このような本質的な思想の親和性から, アートを利用 した科学表現を行うことで科学の本質を表現しやすくな るのではないかと考え，アートを用いています。科学的 に見つかった発見をわかりやすく市民に伝えたり，科学 研究で見られる美しい現象や素材を使ったアート表現を 試みたりするだけでなく，ここで書いた様な科学という 営み本来の姿, 目的を表現していければと考えていま す。実際にアートを用いることで, もともと科学に興味 がなかった人や科学に対して否定的な意見を持つ人とも 対話が可能となり，それまでの科学に対する見方を見直 していただけることなども多くなってきました。

\section{0 科学とアートの協奏がもたらすもの}

私がアートを用いて科学の本質や面白さを伝える活動 を行っているのは, 一般社会における科学の捉えられ方 が私の思う科学とはまったく異なるものであるように感 じているからです。その乘離には強い危機感を感じてい ます。一般社会において, 科学とは, 社会に対して何ら 


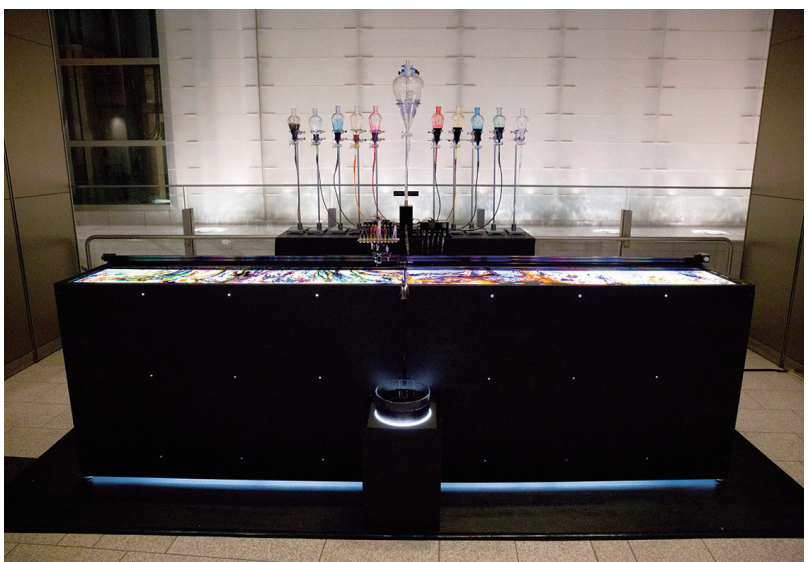

Fig. 6 「dyebirth」(六本木アートナイト2017）およびパレット上で見られるパターン。

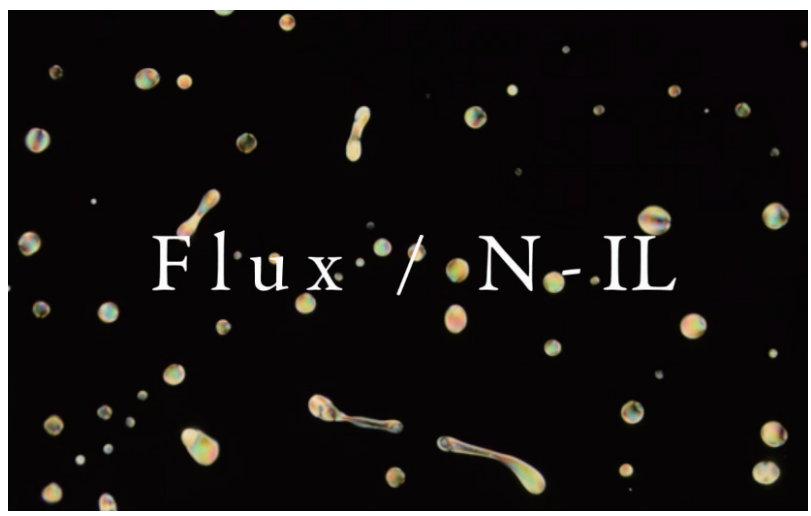

Fig. $7\lceil$ Flux/N-IL」タイトル。

かの役に立つものであるかのように捉えられているよう に感じています。これは科学と技術（テクノロジー）の 境が曖昧なまま世間で広がっているからであろうと考え られます。

しかし前述のとおり，そこには大きな違いがありま す。テクノロジーの目的は何らかの役に立つもの，便利 なものを作り上げることであるのに対し，科学の主体は 自然の理解とそれに対する感動であり，精神的な豊かさ をもたらしてくれるものであるということです。この関 係はアートとデザインのそれと似ています。

アートを通すことでこの科学の役割を一般社会に伝え ていくことができれば，社会における科学の見方や立場が 変わっていくのではないかと信じています。身近な自然を 理解し感動することこそが科学の本質であることを伝え, 科学の裾野を広げていければ幸いです。多くの研究者. 科学者が指摘しているように, 近年日本では, 基礎科学 が軽視され, 研究環境が悪くなっていく一方です ${ }^{27)}$ 。世 の中に㧍ける科学の見方がすこしでも変われば，その環境 をいい方向に変えていけるのではないかと考えています。

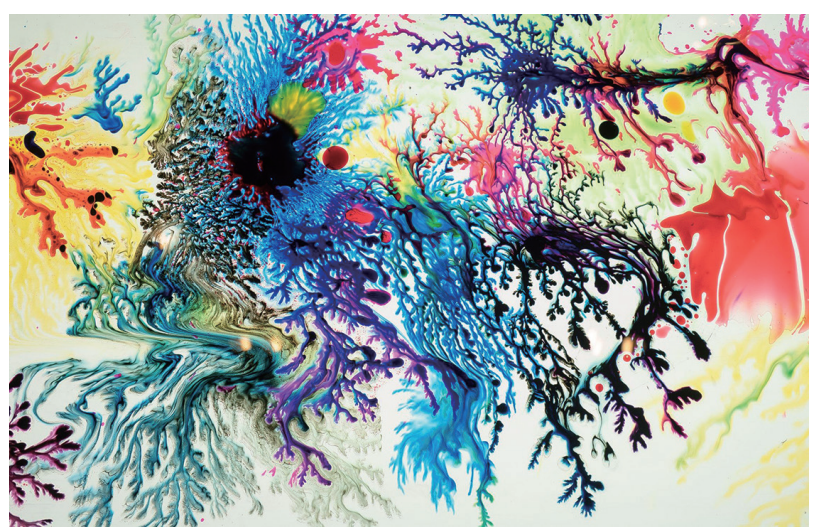

\section{1 おわりに}

本稿でご紹介した作品の動画は私のホームページ 28 で公開しておりますので，ご興味ある方は是非ご覧くだ さい。作品を制作する際にはやはりヴィジュアル的に面 白い現象を用いることが多いため，比較的身近な物質を 用いて目で見て美しい現象が多く観察される油化学やコ ロイド化学, ソフトマター物理学といった分野との相性 は非常に良いと感じています。アート作品にふさわしい 試料や現象をご存知の方がいらっしゃいましたら, 是非, ご教示いただけると幸いです。また，共同制作や広告利 用等のご相談もお待ちしています。最も切実な問題であ る予算に関しても妙案ございましたら，是非ご連絡くだ さい（毎回最も頭を悩ませる点です）。

いずれにせよ，このような活動により，役に立たない と思われがちな基礎科学の認識のされ方が少しでも変化 し，文化としての役割が認められ，社会における立場が 向上すれば，少しでも皆様の扮役に立てるのではないか と信じ，活動を続けていければと思っています。

文 献

1）菱田真史ホームページ https://sites.google.com/site/ mafumihishida/home/research

2) 形の科学会, 形の科学百科事典. 朝倉書店, 東京 (2013). Society for Science on Form, Japan, Encyclopedia of Science on Form. Asakura Publishing Co., Ltd., Tokyo (2013)

フィリップ・ボール, 自然が創り出す美しいパターン シリーズ。早川書店. 東京 (2011).

Ball, P. Shapes: Nature's patterns: A tapestry in three patterns. Hayakawa Publishing Corporation, Tokyo (2011).

3）「抢ちゃか? 第 11 回 自然の形, 色をめでる」小山 田徹氏との対談（大山崎山荘美術館）（Oyamazaki Villa Museum of Art) 
「ここから 何処かへ」國府理氏との対談（京都芸術セ ンター) (Kyoto Art Center)

「本を楽しむ，科学と遊ぶワークショップ」菱田一仁氏 との対談（京都府立図書館）（Kyoto Prefectural Library)

「未来のいえ」國府理氏との対談（西宮市大谷記念美術 館）(Otani Memorial Art Museum, Nishinomiya City)

4) http://www.kenpoku-arthackday.com/

5) https://kenpoku-art.jp/

6) art hack day 1: http://www.kenpoku-arthackday.com/ report-1/day 1

art hack day 2: http://www.kenpoku-arthackday.com/ report-1/day2

7) art hack day 3-4: http://www.kenpoku-arthackday. com/report-1/day3-4

8）「干渉する浮遊体」https://vimeo.com/188372372 メイキング映像 https://www.youtube.com/watch?v= b9YnPxykkeE

9) http://www.kenpoku-arthackday.com/prize

10）干涉する浮遊体チーム https://kenpoku-art.jp/artworks/f13/

11) YouFab Global Creative Awards 2016 FIRST PRIZE WIRED CREATIVE HACK AWARD 2016 パブリック 賞

12）渋谷ヒカリエにて youfab2016 受賞作品展示 https:// www.youfab.info/2016/award-ceremony-report.html

13) BIWAKO ビエンナーレ https://energyfield.org/biwakobiennale/

14）「泡影」https://vimeo.com/291488354

15）神戸新聞 2018 年 11 月 3 日

The Kobe Shimbun, November 3, 2018.
16) $\lceil$ dyebirth $」$ https://nor.tokyo/dyebirth

17）nor ホームページ https://nor.tokyo

18）山本剛宏, 非ニュートン流体中の粘性指状体の挙動. 可 視化情報 22, 235-239（2002）. Yamamoto, T. Viscous fingering in non-Newtonian fluids. J. Visualization Soc. Jpn. 22, 235-239 (2002).

19）今石宣之, マランゴニ対流の基礎, Int. J. Microgravity Sci. No. 31 (Suppl), S5-S12 (2014).

Inaishi, N. Fundamental of the Marangoni convection. Int. J. Microgravity Sci. No. 31 (Suppl), S5-S12 (2014).

20） G. ニコリス，I. プリゴジーヌ，散逸構造. 岩波書店, 東京 (1980).

Nicolis, G.; Prigogine, I. Dissipative Structure. Iwanami Shoten Publishers, Tokyo (1980).

21) https://www.roppongiartnight.com/2017/

22) http://mediaambitiontokyo.jp/2018/

23）国際媒体芸術祭「光点 FLARE2019」http://tdsummit. jp/flare2019/

24）第 22 回文化庁メディア芸術祭 アート部門 審査委員会 推薦作品, PRESENT FUTURE Art \& Technology Star Award 2019, Installation Star Award（中国）

25)「Flux/N-IL」https://vimeo.com/253015243

26）橋本次郎 https://zeit-label.com/

27）文部科学省 令和元年版 科学技術白書

Ministry of Education, Culture, Sports, Science and Technology Japan, White Paper on Science and Technology 2018.

28）著者ホームページ（科学×アートのページ） https://sites.google.com/site/mafumihishida/home/ other 